\title{
Approaching the North: Norwegian and Russian foreign policy discourses on the European Arctic
}

\author{
Leif Christian Jensen \& Pål Wilter Skedsmo \\ Fridtjof Nansen Institute, PO Box 326, NO-1326 Lysaker, Norway
}

\section{Keywords}

Discourse; energy; European Arctic; High North; Russia.

\section{Correspondence}

Leif Christian Jensen, Fridtjof Nansen Institute, P.O. Box 326, NO-1326 Lysaker, Norway. E-mail: Icj@fni.no

doi:10.1111/j.1751-8369.2010.00165.x

\begin{abstract}
The aim of this article is to identify Norwegian and Russian official foreign policy discourses on the European Arctic, and how perceived challenges are understood, framed and presented by the governments in their respective countries. The article makes use of discourse analysis to grasp how the Norwegian "High North" strategy is framed by the Norwegian government and, likewise, how the Russian approach to the European Arctic is framed by the Russian government. The empirical foundation is a study of primary texts such as white papers, official reports, speeches and strategies. We find that the Norwegian approach to the High North features in a powerful official discourse resulting from a robust and broad domestic discursive mobilization. The Russian approach is that of an increasingly assertive nation for which the zero-sum game and relative gains seem to be the main rationale, judging by the official discourse. The Russian approach is not as coherent or based on a broad discursive mobilization as in Norway's case. We identify energy, security, the economy and the environment as key discursive nodal points that the foreign policy discourses of the two countries evolve around: we find that both countries regard the European Arctic's potential as a future energy province to be the region's most prominent aspect. The discourses show that energy is regarded to be of vital national interest, but the countries have differing perceptions on international cooperation. However, as the countries have some important common frames of references, a favourable climate for extended future cooperation could be further developed.
\end{abstract}

In this article we analyse Norwegian and Russian official foreign policy discourses on the European Arctic. Our analysis uses data contained in Norwegian government documents, key speeches by Russian President Putin and official documents from Russian authorities. We use these texts to map how challenges and opportunities in the European Arctic are perceived and framed in Norway and Russia by the authorities. As neighbouring states, the two countries will always have to reach an accommodation with each other in the North, and work closely together from time to time on certain issue areas. Among already existing collaborative arrangements we find the Joint Russian-Norwegian Fisheries Commission (established in 1975) and the Joint Commission on Environmental Protection (established in 1988). In addition, Norway and Russia cooperate on the multilateral level within the framework of the Barents Euro-Arctic Region, established in 1993, and the Arctic Council (1996). However, it is not within the scope of this article to assess or evaluate these collaborative arrangements. Literature on such arrangements in the Arctic (Stokke \& Hønneland 2007), on cooperation on fishery management (Henriksen et al. 2006; Hønneland 2006), on relations between the military and the non-military sectors (Åtland 2008, 2009), and on discourses on environmental cooperation between Russia and the West (Hønneland 2003) is a relevant backdrop to our study. Our aim, though, is somewhat different as we explore what the foreign policy discourses in both countries say with regard to the perceived opportunities and challenges in the European Arctic. Discourse plays a crucial part in understanding politics and policies because ultimately it is through language we understand, construct and make sense of the world.

The European Arctic is at the head of the Norwegian political agenda in a way that has not been seen since the days of the Cold War. It is especially apparent in 
the significant discursive mobilization of recent years, comprising an increased production of government documents and a widening debate in the Norwegian media (Jensen 2007; Hønneland \& Jensen 2008). In March 2003, the Norwegian Ministry for Foreign Affairs put together a High North commission, which resulted in an official Norwegian report in December the same year (ECNA 2003). In the autumn of 2005, the newly elected coalition government officially declared:

The Government regards the Northern Areas as Norway's most important strategic target area in the years to come. The Northern Areas have gone from being a security policy deployment area to being an energy policy power centre and an area that faces great environmental policy challenges. This has changed the focus of other states in this region. The handling of Norwegian economic interests, environmental interests and security policy interests in the North are to be given high priority and are to be seen as being closely linked. (Office of the Prime Minister 2005)

The Norwegian Government's High North strategy (Ministry of Foreign Affairs 2006) and New building blocks in the North (Norwegian Government 2009) set out to translate the government's ambitions into practical challenges and opportunities facing Norway in the North. Norwegian action and foreign policy interests in the European Arctic depend on relations at several levels with Russia. There is little mention in official discourse or public media concerning the Russian authorities' perceptions of the European Arctic. In this article we use discourse analysis to interpret the framing of the official discourse in Norway, and attempt to do something similar on the Russian side. We formulate the following research questions. How are the approaches to the European Arctic framed through the foreign policy discourses in Norway and Russia, and what are the discursive nodal points these discourses evolve around? We start out with a description of our theoretical and methodological point of departure. We then turn to the specific question posed above, and commence our analysis of foreign policy discourses in Norway and Russia.

\section{Point of departure}

There are many ways to depict and analyse policy formations, but as mentioned above we have opted for a discursive approach. Discourse analysis is-although the name could indicate otherwise-an integrated theoretical and methodological approach to analysis. It is a complete package containing epistemological premises concerning the role of language in the social construction of the world. In The archaeology of knowledge (1972), Foucault's point of departure is that there exists a set of rules that decides which statements will be accepted as both meaningful and true within a specific historical context. This implies that he understands discourse as including something in addition to speech, words and text. Discourse is where meaning is constituted and established, as representations of the physical world are negotiated and confirmed. When any given representation is institutionalized, it gains hegemony. Discourse theory is concerned with epistemology, e.g., how meaning and knowledge are created and reproduced, rather than with ontological premises, which concerns itself with the basic nature of things, the essence of "being" itself (Neumann 2001; Schiffrin et al. 2003). Discourse analysis contains theoretical models and methodological guidelines about conducting research in a given field. Lastly, it offers special techniques for analysing language as data. Discourse analysis combines theory and method, and it is essential to accept its basic epistemological principles outlined above before using it as a method in research (Winther Jørgensen \& Phillips 1999). We decided, therefore, to present theory and method under the same heading to illustrate this general point, and because it makes sense from a practical point of view. For the same reasons, we do the same for the presentation and analysis of our data.

We define a discourse as "an interrelated set of texts, and the practices of their production, dissemination, and reception, which brings an object into being" (Parker 1992; quoted in Phillips \& Hardy 2002: 3). For example, a body of texts of various kinds related to development and environmental management has brought the concept of sustainable development into being, and these discursive practices continue to affect the discourse on sustainable development. As Philips \& Hardy note:

Discourses are embodied and enacted in a variety of texts although they exist beyond the individual texts that compose them ... Texts are not meaningful individually; it is only through their interconnection with other texts, the different discourses on which they draw, and the nature of their production, dissemination, and consumption that they are made meaningful. (Phillips \& Hardy 2002: 3-4)

One uses discourse analysis to understand how change occurs or status quo is maintained through processes of embedding, or as part of an already established hegemony in political discourse. The implications of political discourses on the respective domestic scenes in Norway and Russia are that we, as analysts, are looking at constraints that shape their foreign policies-a kind of framework within which the foreign policy of either country can take place (Larsen 1997). What we will try to do in this article is to show how, whether in Norway or Russia, foreign policy issues are framed as certain topics 
are included and others excluded in discourse. Further, we will look for what Laclau \& Mouffe (1985) brand nodal points. The central implication is that discourses evolve around certain concepts or statements that tend to have a privileged standing within the discourse. This said, such nodal points can only "obtain partial fixation" (Åkerstrøm Andersen 2003: 51) because they will always be in the midst of discursive battles, and because discourses are always in flux. Still, certain concepts will be less disputed, and treated more as truisms, than others.

The discourse analyst interrogates taken-for-granted meanings in texts from the specific setting she reads. Combined with relatively small and context-specific data sets this critical potential makes it difficult to claim external validity (Tonkiss 1998). But, “[d]iscourse analysis fits into a broad range of social research methods which between them seek to analyse general social patterns but also to examine the devil in the detail" (Tonkiss 1998: 260). Thus, the analyst seeks to establish internal validity, or at least a plausible narrative (Czarniawska 2004), which, in addition to being interesting and having a value in itself, hopefully will say something of more general significance, even though it will not be generalizable in a strict positivist methodological sense.

There will always be other points of view that see reality differently, and it is possible to identify alternative discourses. However, the purpose of this article is to take a closer look at what we term official foreign policy discourses in Norway and Russia related to the European Arctic. These discourses have to be constructed by us an analysts based on a plausible interpretation of the empirical data available. They are not preformed entities, "ready to be plucked from the air and waiting to be identified" (Jensen 2007: 248).

Another more fundamental matter is what we can do to convince you as a reader that our representation is accurate and fair. According to a social constructivist theory of knowledge, where a given representation of the world is just one of many possible representations, it is an unanswerable question (Winther Jørgensen \& Phillips 1999). Naturally, other choices could be made and other discourses explored. Our delimitations and constructions are, however, based on an assumption that they best represent the slices of reality we seek to convey (Hønneland 2005). This assumption relies in turn on our document studies that we believe offer a solid vantage point on the most typical and relevant aspects of Norwegian and Russian foreign policy discourse in the North since the turn of the millennium.

Discourse analysis gives epistemological and methodological priority to the study of primary texts (Hansen 2006), such as presidential statements and official policy documents that are our main sources of data in this study.
These so-called monuments (Neumann 2001) or primary texts are often created in the context of an ongoing discursive battle and have, at least in theory, formed, absorbed and grasped the strongest representations. When selecting primary texts, we were at pains to meet the following three criteria: the texts should be characterized by the clear articulation of identities and policies; they should be widely read and attended to; and they should have the formal authority to define a political position (Hansen 2006). We argue that our chosen texts score high on all of these criteria, and can therefore with relative confidence be branded primary texts or monuments in what we define as the discursive field of the European Arctic. Russian presidential statements are taken into account and referred to by politicians and the public-and by governments-throughout the world. And equally important, the selected texts are all articulated by formal political authority, which is of course crucial as they are intended to represent the countries' approaches to the European Arctic. The texts can also have or acquire power by repeating, confirming, strengthening and/or qualifying a certain ideological position, and by their context-specific appearance. They both have and generate power by being perceived as relevant and important enough to participate and take centre stage in such important discourses (Berge 2003). Texts like the ones making up our data set the agenda and shape the issues at hand, and they frame and produce representations of foreign policy. Powered by their respective roles as institution or president, the actors have a certain authority and power to define how reality should be perceived (Berge 2003; Hansen 2006). In addition, they enjoy official prestige and authority as speech acts (Searle 1969). It is up to policymakers and bureaucrats on either side to give these policy statements and speech acts substance, and respond with practical steps in the policy areas in question. In this article we decided to leave the "practical steps" alone, and concentrate on the discursive level. Obviously, in politics, as in life in general, what is being said and what is being done are frequently at odds. On the other hand, statements from a Russian president, in light of his extensive executive powers, should not be underestimated, even though the statements are-as this article will show-often rather general.

All quotations in this article, which are used as documentation, exemplification and representation of the Norwegian foreign policy discourse, are taken from officially translated versions of the following public documents: The Norwegian Government's High North strategy (Ministry of Foreign Affairs 2006), The Soria Moria declaration on international policy (Office of the Prime Minister 2005) and the white paper Opportunities and challenges in the North (Ministry of Foreign Affairs 2005). In addition, we have analysed the official Norwegian report Towards 
the North! Challenges and opportunities in the High North (ECNA 2003) and New building blocks in the North: the next step in the Government's strategy for the High North (Norwegian Government 2009). These documents are not available in officially translated English versions, and the translations of these and various media sources are our own. On the Russian side, we selected President Putin's annual addresses to the Federal Assembly throughout his two presidential terms in 2000-08 as the key documents (Putin 2001, 2002, 2003, 2004, 2005, 2006, 2007). We studied the speeches in the original Russian language version, available at the Russian president's official website, but for the purpose of this article we use the officially translated versions made available through the same website. We also rely on the Energy strategy for Russia towards 2020 (Gazprom 2003), President Putin's address to the State Council on Russia's development strategy (Putin 2008) and Russia's Arctic strategy issued by the Russian Security Council (2009a) to get a more elaborate understanding of Russia's approach to the European Arctic. An official English summary is available for the Energy strategy; Putin's address to the State Council is available in an official English translation; and the Security Council's Arctic strategy has been translated from the original Russian by the authors. Albeit general in perspective, such documents portray tendencies over time, have the authority to define an issue and enjoy epistemological priority (Hansen 2006).

\section{Norwegian High North discourse}

Skagestad (n.d.) observes that the phrase "High North" was introduced as the English equivalent of the Norwegian term nordområdene (the northern areas) in the mid1980s, eventually becoming adopted by the Norwegian authorities at the beginning of the current century. According to Skagestad: "The concept has no immediate corresponding counterpart in academic or political discourse outside of Norway, and it is not self-explanatory to foreigners" (n.d.). The official Norwegian understanding of the "High North", at least geographically, was presented in the Norwegian Government's High North strategy (Ministry of Foreign Affairs 2006), which was released on 1 December 2006.

The High North is a broad concept both geographically and politically. In geographical terms, it covers the sea and land, including islands and archipelagos, stretching northwards from the southern boundary of Nordland County in Norway and eastwards from the Greenland Sea to the Barents Sea and the Pechora Sea. In political terms, it includes the administrative entities in Norway, Sweden, Finland and Russia that are part of the
Barents Co-operation. Furthermore, Norway's High North policy overlaps with the Nordic co-operation, our relations with the US and Canada through the Arctic Council, and our relations with the EU through the Northern Dimension. (Ministry of Foreign Affairs 2006: 13)

The same government's definition of the High North seemed to have opened up somewhat three years later.

The Government's policy does not give a precise definition of what it reads into the expression "the High North", nor whether it limits the High North to Norwegian territory. Substantial Norwegian interests are likely to be affected by developments wherever they take place in the circumpolar and Arctic region; indeed, international terminology tends to use "High North" and "Arctic" more or less synonymously [in fact, the term "High North" is not employed in international discourse; see Skagestad (n.d.)]. Norway's strategic High North policy exists in a certain geo-political environment. Norway remains committed to maintaining its active dialogue with neighbours, partners and allies on matters related to the High North, and to do more to promote Norway's High North policy in international and regional forums. Wider international cooperation in the High North and circumpolar areas, and with Russia in particular, should prove beneficial for our part of the country as well. (Norwegian Government 2009: 7; translated by the authors)

It is interesting to note how the very precise geographical definition in the 2006 document has disappeared in favour of a vaguer and more open-ended understanding of the High North. Such a change could very well indicate some sort of shift in the Norwegian approach, or at least be a symptom of a change in priorities, focus or direction in the government's approach to the High North. The more general point one could make from this is that the texts are clearly interrelated, but at the same time are different enough to make us see that discourses are dynamic and always in flux.

The main purpose of the government's High North strategy is to "coordinate efforts in all fields relating to the development of the High North" (Ministry of Foreign Affairs 2006: 5). Furthermore, the overall objective of the government's policy on this matter is to "create sustainable growth and development in the High North" (Ministry of Foreign Affairs 2006: 7). Such a sentiment was formulated in a very similar way by the previous government three years earlier. This shows how the discourse consists of an "interrelated set of texts" (Parker 1992 quoted in Phillips \& Hardy 2002: 3).

Through the active use of natural resources, a pro-active foreign policy and high environmental 
standards, Norway intends to make the High North a model of sustainable development, where culture and nature provide the foundations of innovation in commerce and industry and collaboration between nation-states. (ECNA 2003: 9; translated by the authors)

The High North has been revitalized by a discourse on the prospects that the Barents Sea could become a new, strategically important petroleum province. This discourse was apparent in public documents under other governments before the High North was declared top priority in the autumn of 2005.

There are also major challenges in the foreign policy field. Other countries are showing a growing interest in Norwegian and Russian petroleum resources. This is partly because these resources are located in politically stable areas, and many countries are concerned about securing their energy supplies. This makes the High North more interesting than many other areas that are rich in energy sources. Periods when there is an insufficient supply of energy may give rise to high expectations and political pressure. It cannot be taken for granted that Norwegian interests will always coincide with those of key partners. It is therefore important to ensure that Norway's interests continue to determine developments in the Norwegian part of the High North. (Ministry of Foreign Affairs 2005: 7)

And this was reiterated and made concrete as part of placing the High North at the top of the policy agenda by the current government one year later.

The Government's aim is that Norway will be the best steward of resources in the High North, with oil and gas operations that meet very stringent environmental standards, and with continual knowledge generation, research and development in the petroleum sector ... It is also likely that the Barents Sea will become increasingly important in the global energy supply context due to the political will in many countries to reduce dependency on supplies from the Middle East. The resources in the Barents Sea could provide long-term secure energy supply to the markets in Europe and the US within a sustainable framework. (Ministry of Foreign Affairs 2006: 55)

A consequence of not having found a Norwegian equivalent to the giant Russian gas field Shtokman (Shtokmanovskoye) was that the main focus in the public High North debate in Norway was slowly turning towards what might or might not happen petroleum-wise on the Russian side. This was regarded as important, whereas speculation reached new levels on what role Norway and Norwegian companies could or could not play in different outcomes. Sentiment in general, mirrored and powered by the media coverage (Hønneland \& Jensen 2008) since the High North became a major concern in Norway, swung largely in step with signals coming out of the Kremlin and Gazprom headquarters. Questions about Norway's potential role in the development of the Shtokman field have flourished, and have set the tone and the pace of public discourse through the Norwegian media: a quotation from a story in a major Norwegian financial newspaper represents this in a telling way.

Confirmation came yesterday from [the Norwegian energy company] Statoil and the Norwegian Petroleum Directorate that the well known as Uranus, sited $125 \mathrm{~km}$ north-east of Nordkapp [in northern Norway], was dry. The announcement came just as the Barents fever was about to infect all of us. [The northern Norwegian town of] Hammerfest is sinking under the weight of Snow White money [a reference to a major liquefied natural gas extraction project]. The Italian oil conglomerate Eni wants to develop the Goliath field [off northernmost Norway]. Statoil and [the Norwegian energy company] Hydro want to be part of Russia's gigantic Shtokman development. Norwegian foreign minister Jonas Gahr Støre talks so incessantly about oil and the High North, he wouldn't look amiss in a boiler suit and hard hat. Oil expert Johan Petter Barlindhaug, who enjoys the backing of the government and Statoil, has turned the map upside down in declaring northern Norway the centre of Europe's next oil Klondike. Behind everything glow increasingly seductive oil and gas prices. It is probably only the Socialist Left Party and a handful of aggravated environmentalists that want to slow the pace, setting their hopes on the integrated management plan for the Barents Sea, due out before Easter. Ironically, the most dependable ally of the environmentalists at the moment could be the geology of the Norwegian Barents Sea. The dry Uranus hole is not the first geological let-down to face oil devotees. Since the summer of 1980, sixty-five wells have been drilled up north, resulting in only two promising fields: the Snow White gas field and the Goliath oil field. And in southern Norwegian terms, they are not particularly extensive either. (Løvås 2006: 2; translated by the authors)

One of the main characteristics of Norway's High North strategy remains the discursive mobilization, not least in newspapers nationwide (Jensen 2007; Hønneland \& Jensen 2008). A wide range of actors have felt called to explain their views, although nothing significantly has really happened materially in the North since the debate began. The urgency of issues concerning the High North 
can also be defined in terms of speech acts: as a region that is "talked and written into existence" (Neumann 1994: 59) in much the same way as the Barents EuroArctic Region itself was one and a half decades earlier. Instead of postulating a given set of interests, a regionbuilding approach investigates interests where they are formulated, i.e., in discourse. In addition to its place at the top of the political agenda, the High North is clearly of considerable interest to the general public. One could even say that the texts and utterances of the Norwegian Foreign Minister have in fact revitalized the dynamics of the High North debate. Policy documents have framed the issue in a certain light, and have approached the High North from a certain angle, which has made us understand, talk and act in a certain way. On the other hand, the documents and the public deliberations have reinforced, cultivated and shaped one another. The documents have given rise to opinions, and the public discourse has shaped the next policy document, and vice versa (Jensen 2007; Hønneland \& Jensen 2008).

The Norwegian government has made an open commitment to protect and promote interests in an area of great opportunities and increasing civil strategic importance.

Norwegian interests in the High North will be safeguarded primarily by strengthening our presence and increasing the level of activity in a number of policy areas at both national and international level.

(Ministry of Foreign Affairs 2006)

For instance, it would mainly be up to the Norwegian Ministry of Defence to figure out what practical measures need to be taken by the Norwegian Navy and Coastguard in order to live up to the promise of a strengthened presence in the High North. Thus, we see how foreign policy discourses must not only be interpreted by outsiders, such as academics and observers abroad, but also by parts of the state apparatus. If the political discourse, as voiced by its most eager ambassador-the Norwegian Minister of Foreign Affairs-is to be taken seriously, for instance, the threat of a discursive practice like deploying Norwegian Armed Forces if necessary must be deemed credible by outsiders.

As the document makes clear, foreign policy and national policy ambitions are merging and growing ever more tightly linked discursively: development in the north of Norway, cooperation with Russia and absolute, mutual gains (Keohane \& Nye 1977) are exemplified by the following two quotations.

It is the Government's strategy to facilitate the further development of a knowledge-based business sector in the High North, with particular focus on seizing the opportunities in the resource-based sectors. A strong knowledge base in North Norway will also be important for the development of cross-border business activity between Norway and Russia. (Ministry of Foreign Affairs 2006: 65)

Norway's partnership and commerce with Russia are surging ahead. Increasing numbers of Norwegian businesses now have a stake in north-west Russia, and contact across the border is greater than ever. Norwegian and Russian businesses are establishing partnerships across ever wider areas. The authorities will take steps to accelerate capacity, building in the private sector in the High North, and promote Norwegian business interests in Russia. (Norwegian Government 2009: 50; translated by the authors) Moreover, this follows from the main theme of the strategy, which is to "give our [the government's] policy a more coherent High North focus" (Ministry of Foreign Affairs 2006). In addition to pursuing high politics and protecting vital Norwegian national interests from foreign actors, tighter integration is considered "a question of a broad long-term mobilisation of our own strengths and resources in the development of the entire northern part of our country" (Ministry of Foreign Affairs 2006: 5).

The Norwegian approach ranges across issues as diverse as safeguarding the livelihoods, traditions and cultures of indigenous peoples in the High North, promoting peopleto-people cooperation, and developing policy on future petroleum activities in the Barents Sea (Ministry of Foreign Affairs 2006). Public sentiment declined noticeably after Gazprom, the Russian energy company in which a controlling stake is held by the Russian state, announced in October 2006 that it would proceed with the development of Shtokman without Norway (i.e., excluding Statoil or Hydro). All the same, after it became known in October 2007 that the newly merged StatoilHydro company would be a partner with Gazprom and Total-with President Putin calling Prime Minister Stoltenberg to personally break the good news-Norwegian media redoubled their coverage, and a spirited High North debate ensued. Judging from the media debate in the following weeks, Putin and Russia had literally saved the day in the High North, and helped give the Norwegian strategy renewed vitality and substance. Perhaps one of the reasons the High North strategy has not really taken off, despite a massive effort by the government, was the lack of success displayed-materially-on the ground. The government clearly found it difficult to convince the public of the material advantages of the enterprise.

\section{Russian policy discourse on the European Arctic}

As outlined above, our study of the Russian policy discourses related to the European Arctic rests on a study of 
documents we, in line with Hansen (2006), hold that are primary texts, which have epistemological priority to the discourse analyst. On the Russian side, there is to a lesser extent a readily apparent policy discourse corresponding to Norway's ambitious High North policy. The Russian alternative to Norway's intense discursive mobilization is conspicuous by its absence. This is not to say that Northern politics is not discussed in Russia, but that it seemingly does not match the forceful debate that has taken place in Norway over recent years.

Parliamentary committees, such as the Committee on Northern Territories and Indigenous Minorities Issues in the Council of the Federation (Komitet Soveta Federacii po delam Severa i maločislennyh narodov) have fairly little power, and the legislation in Russia is weaker than the executive powers of the president. Yet more powerful is the Russian Security Council, a consultative body to the president. The Security Council have, among others, issued a strategy for Russia's Arctic policies up to 2020 (Russian Security Council 2009b).

The presidential statements analysed in this article are rather general in perspective, and, combined with a seeming lack of media discourse on Arctic issues in Russia, could be interpreted to indicate a lack of discursive mobilization in Russia. Although issues related to the European Arctic are debated and discussed in the Russian media, our assessment of Russian public discourse is that issues related to the Arctic do not take on the same prominence or importance as they do in Norway. This observation is based on our day-to-day reading of various Russian media sources. Let us now turn to what the existing data sources from Russian political authorities tell us about the Russian approach to the North. Firstly, we note that the official discourse in Russia conveys a rather fixed view on foreign policy, the rationale and implications of which were clearly summed up by the president.

We are building constructive, normal relations with all of the world's nations-I want to emphasise, with all of the world's nations. However, I want to note something else: the norm in the international community, in the world today, is also harsh competition-for markets, for investment, for political and economic influence. And in this fight, Russia

needs to be strong and competitive. (Putin 2002) Although futile legally (Jensen 2008: 585), when a Russian submarine planted the Russian flag on the seabed at the North Pole in 2007 (Parfitt 2007), such a discursive practice (Neumann 2001) can be taken as an example of Russia's increasing assertiveness. Does this imply that Russia is pursuing a more confrontational line than Norway? President Putin has his own views on the West's interference and interpretations of Russian policies.
It is far from everyone in the world that wants to have to deal with an independent, strong and self-reliant Russia. Political, economic and information pressures have become weapons in the global competitive battle today. Our efforts to strengthen our state are sometimes deliberately interpreted as authoritarianism. In this respect I want to say that there will be no going back on the fundamental principles of our politics. (Putin 2004) The Russian president appears to retain the notion of foreign policy as a game, where what is in one state's interests is automatically in conflict with those of others (Morgenthau 1973). In Russian political sciencepolitologija-relations between states are typically perceived as a zero-sum game where one state's gain is another state's loss. So Norwegian financial support for different projects on the Kola Peninsula, however well intended, risk being perceived ambivalently by Russian authorities, or even as instances of hostile strategic interference (Skedsmo 2005). As Russia balances between a desire to be a reliable trading partner and more hawkish foreign policy aspirations, one notes a sense of antagonism between integration and security, insofar as integration could lead to dependence and a narrowing of the strategic options available (Larsson 2006). The Russian president sees this as a global battle for access to strategic resources.

In this context, it is understandable that the world should be showing growing interest in Russia and in Eurasia in general. God was generous in giving us natural resources. The result is that we are running up against repeats of the old "deterrence" policy more and more often. But what this usually boils down to, essentially, are attempts to impose unfair competition on us and secure access to our resources. (Putin 2008)

Russia's understanding of foreign relations as a zero-sum game, where energy takes centre stage, is at odds with Norwegian sentiments, where mutual gains are seen to be within reach in international relations. Whatever its perspective on foreign relations, Norway will have to accept Russia's newfound assertiveness after a historically exceptional period of economic turmoil in the 1990s, during which Norway to a greater extent could set the agenda for collaborative arrangements in the North (Hønneland 2003, 2005). It was a historical and political anomaly, not likely to be experienced again in the foreseeable future.

If energy policy is understood-as one observer notes-to be the "sword and shield of Russia's security policy" (Larsson 2006: 291), this could indicate that energy is first and foremost understood in terms of security in Russia. Indeed, the fact that Russia's Arctic strategy 
(Russian Security Council 2009a) is published by the Security Council could possibly be interpreted as some form of a securitizing move (Waver 1995) on Russia's behalf. However, this rather generally formulated document actually emphasizes several other features of the Arctic rather than military security, and is to be found under the heading of "Economic security" (Ekonomičeskaja bezopasnost') on the council's website (Russian Security Council 2009b). The document outlines a number of focus areas for the Arctic: the Arctic's potential as a strategic resource base, the Arctic as a zone of peace and international cooperation, the Arctic's unique ecosystem and the possibilities for new transport routes. The document states that Russia is troubled by what it sees as the increased militarization of the region (Russian Security Council 2009a). On the other hand, it states that the main goal in the third phase leading up to 2020, e.g., from 2016 to 2020, is to secure and transform Russia's Arctic zone to have the leading role as the strategic resource base for Russia. Media reception in the West has largely focused on the "deployment of an Arctic force" (BBC 2009) and similar issues (Isachenkov 2009; Parfitt 2009), but this is perhaps more telling of how the West still interprets Russia's actions in Cold War terms. In the Russian media, a spokesperson of the Security Council downplayed the issue related to the deployment of an Arctic force (Borisov 2009). To sum up, we find Russia's Arctic strategy to be rather general and cautious in its approach. However, it shows that Russia fully acknowledges the potential of its Arctic areas to secure the socioeconomic development, and it is in this sense that it seems most reasonable to interpret the document.

To utilize the Arctic zone of the Russian Federation as a strategic resource base for the Russian Federation in order to secure the socio-economic development of

the country. (Russian Security Council 2009a)

Possibly in contradiction to Russia's wish to protect its strategic resources is its expressed need for foreign investments and technology for its extraction sector. Putin has touched on the sector's need of investments on several occasions. The general message seems to be that Russia wants to attract and encourage foreign investors, but keep foreign interference well away from the strategically important sector.

We already feel confident in the mining and extraction sector. Our companies in this sector are very competitive. Gazprom, for example, has just become the third biggest company in the world in terms of capitalisation, while at the same time maintaining quite low tariffs for Russian consumers. This result did not just come about all on its own, but is the result of carefully planned action by the state. (Putin 2006)
Political discourse matters, but it is connected to materiality such as the demand and delivery of petroleum. Securing the latter requires a favourable investment climate and transparent regulation of property rights. Putin has addressed ways of encouraging investment in several speeches.

We must take serious measures to encourage investment in production infrastructure and innovative development while at the same time maintaining the financial stability we have achieved. Russia must realise its full potential in high-tech sectors such as modern energy technology, transport and communications, space and aircraft building. (Putin 2006)

Although Russia seems to be lagging behind in terms of exploration, the investment climate is uncertain at best. Although of growing concern, there are no signs as of yet of a reform of the energy sector. Russia's need for investment and technology is directly related to discussions on foreign participation and partnership. For instance, recognizing the inefficiency of the operating fields shows that Russians understand the need for foreign investments and solutions.

Yet another problem is that Russian oil fields burn more than 20 billion cubic metres of accompanying gas every year, and that is the minimum estimate. And yet, elsewhere in the world, there is a whole system of measures that has already proven its effectiveness. (Putin 2007)

Although StatoilHydro is involved in the development of the Shtokman field, it remains to be seen to what extent Russia opens the door for foreign investment and participation. Previous vacillation on foreign participation in Shtokman does not bode well for those hoping for a transparent and consistent policy to emerge.

Russia inherited the Soviet subsidy system of the North (Blakkisrud \& Hønneland 2006a), and President Yeltsin oversaw its continuation. The Soviet Union was characterized as "an administrative ordering of nature and society, a high-modernist ideology, an authoritarian state and a prostrate civil society that lacks the capacity to resist these plans" (Scott 1998: 4-5). These traits are not, however, only relics of the past: the same mechanisms can still claim some relevance today. A hallmark of the system was the inherently territorial tenor of Soviet High North policies: the North was considered to be a world apart, the complex challenges of which should be seen and resolved as a whole.

... the main problem facing today's Russian government is neither the space in itself nor its northernness, but the fact that it has inherited an economic geography established in deliberate 
defiance of the constraints of both distance and climate. (Blakkisrud \& Hønneland 2006b: 193) The post-Soviet presidential administrations have struggled to hammer out an acceptable power-sharing agreement between the regional and federal governments, asYeltsin encouraged the regions to "take as much sovereignty as they could swallow" (Blakkisrud \& Hønneland 2006a: 13); whereas President Putin has sought to strengthen the executive.

We set ourselves the objective of building an effectively functioning executive vertical power structure ... A year ago it was clear that in order to ensure the success of the strategic transformations we wished to undertake, we would have to bring order to relations between the federal and regional authorities, and that not having clearly delimited powers and effective mechanisms for cooperation between the different levels of power would result in greater economic and social losses. We need a consolidated and effective state power system in order to act on urgent social and economic problems and security issues. (Putin 2001)

Increasing centralization seems to have been an important theme of both Putin's terms in office. However, perceptions of the North lost much of their territorial anchor, and became functional (Blakkisrud \& Hønneland 2006a). In light of the dismantling of the Soviet system of subsidies, the profitable North has moved into the fore, sidelining unprofitable areas that have had to accept a diminishing role and less attention. The North as a future energy province is what really matters, as several of the quotations above indirectly confirm. However, certain securitizing moves are deployed by Russia, although this should not be exaggerated. But slightly more hawkish rethoric and practices set Russia apart as an ambitious nation aiming to regain superpower status, compared with the more collaborative tone emanating from Norway.

To sum up, official Russian discourse appears fragmented compared with Norwegian discourse. As noted above, a wide and public debate over Russia's policy to the North is almost absent compared with Norway. The way in which Russia's Arctic strategy was published illustrates this: rather than being forcefully branded, as the Norwegian High North strategies have been, with several cabinet members participating at press conferences, Russia's Arctic strategy was published relatively discretely, with just a press release on the Security Council's website. However, it was soon picked up by Russian and international media.

Vacillating about partnerships for the Shtokman development could seem to suggest a rather incoherent policy on the North in general, and particularly on offshore development. Certain fundamental principles are clearly voiced in the dominant political discourse, although market principles do not always march in step with the protection of strategic resources, and in this sense, national control seems to be the fundamental and prevailing narrative. It should also be noted that this rivalry between securing the interests of the state and letting the private sector go about its business in a relatively uninhibited fashion will probably continue to form Russian policy discourses. Embedded within Russian political discourses on energy, foreign intervention and business participation compete with concerns to safeguard strategic resources, not to mention the strengthening of executive power. Thus, we find that Russia does not have a consolidated foreign policy discourse focusing on collaboration and development of business in the European Arctic. Furthermore, Russia does not have an equivalent to the forceful discursive mobilization overseen by the Norwegian government. On the contrary, Russian policies related to the Arctic are embedded in other political discourses, such as discourses related to security and sovereignty, and development of the country's socioeconomic situation. A central implication of this is that Russia's approach to the Arctic could perhaps be said to be more functional and ad hoc than Norway's more holistic and all-inclusive approach.

\section{Sharing discursive nodal points in the North}

In this article we have analysed Norwegian and Russian foreign policy discourses on the European Arctic. These discourses contain certain nodal points that partially fix the discourses. Perceptions and discourses evolving around nodal points are embedded in the historical experiences and different political traditions of the two nations. Based on the empirical data discussed so far we have identified four nodal points that the Norwegian and Russian foreign policy discourses on the European Arctic evolve around. These are energy, security, the economy and the environment. The four nodal points are perhaps not surprising in themselves, but by way of identifying them and showing how they are emphasized in discourses, this can shed new light on the Norwegian and Russian approaches to the European Arctic.

We have witnessed the Norwegian discourse on its Northern politics speed up significantly since 2005. We have seen how the Norwegian approach to the High North features in a powerful official discourse resulting from a robust and broad domestic discursive mobilization. Official Norwegian messages are consistent, seeking to balance Norway's global position as a small state with energy-driven ambitions in the European Arctic. This dual role of small state and big player results in a foreign 
policy discourse that seems to be as much about getting the attention and backing of friends and allies, as it is about minimizing meddling in the sphere of Norwegian interest. The aim seems to be to leave as much room for manoeuvring as possible. The approach is coherent in the sense of seeking to embrace everything associated with the North, such as fisheries, indigenous people and the protection of endangered species. The official Norwegian discourse clearly rides on an energy plot, and on the perceptions of the European Arctic as a future petroleum province of regional or even global significance. Armed with cutting edge technology, but lacking viable known reserves, Norway remains firmly focused on pursuing mutually beneficial relations with Russia.

The Russian approach is that of an increasingly assertive and self-confident nation, for which-judging by the official discourse-the zero-sum game and relative gains seem to be the main rationale. Nevertheless, the Russian approach is not particularly coherent or based on a broad discursive mobilization in the same way as the Norwegian approach. Rather, it embodies a more functional approach to petroleum as a vital strategic resource. The North as such lacks the same discursive position in Russia as in Norway. It is not hard to see that Russia seems reluctant to give up control over vital and strategic resources, and the prevailing zero-sum thinking can seriously dampen the prospects of fruitful relations in the areas of technology and business with Western countries on the Russian continental shelf. Given Russia's habit of sending mixed messages_calling for cooperation, while blaming the West in general, and NATO in particular, for expansionism-Russia may look as if it lacks a coherent strategy, or one that resists interpretation. But on the other hand, speeches given by former President Putin do send a rather consistent message concerning Russia's priorities. Despite our finding that Russia does not have a coherent discourse on the Arctic, to the extent that Norway has on the High North, our data suggest that Russia's approach to the Arctic evolves around corresponding themes.

We find that both countries regard the European Arctic's most important feature to be its prospects as a resource province, with more or less emphasis on security. Norwegian and Russian discourses are both oriented towards protecting national interests, albeit the rhetoric is definitely more assertive on the Russian side. Calls for collaboration in business development have certainly been an issue, especially when the much-debated Shtokman field is in the picture. But as Norway expressed fresh optimism after StatoilHydro was taken on board by the Russians, Norway still seems to have a problem with its image, both at home and abroad. The already difficult task of projecting a credible image as a world leader in envi- ronmental friendliness, while overseeing an economy that is hostage to fossil fuels, is particularly apparent in the High North. Being a credible steward and protector of the environment while earning money from petroleum extraction in the very same region is extremely difficultat least to communicate convincingly. In Norway, the petroleum debate related to the Barents Sea has pitted extraction against protection: as the argument for extraction goes, it would be better for the environment if Norwegian petroleum companies did the drilling because they know more about environmentally friendly drilling than their Russian counterparts (Jensen 2007). That Norway is a better friend of the environment than Russia is a broad and largely unquestioned assumption in the Norwegian public sphere. In its energy strategy, however, Russia admits facing "a lot of ecological problems" (Gazprom 2003). They will be addressed by developing "low-waste technologies", and steps will be taken "to come closer to the European ecological standards" (Gazprom 2003). Perhaps needless to say, Norwegian perceptions of their own and Russia's environmental capabilities have practical consequences in terms of how Norway as a country approaches Russians and challenges in the North, where Russia is both part of the problem and part of the solution.

Finally, based on the four common nodal points it is tempting to ask whether the Norwegian and Russian approaches to the European Arctic are that different after all? Both countries are producers, and share complementary needs and assets: Russia admits to a lack of technological competence in offshore drilling under demanding conditions such as the Arctic, whereas Norway is worried about a shortage of viable petroleum fields in the Norwegian sector of the Barents Sea. There are discursive and material forces pulling in different directions, making the climate for extended bilateral cooperation far from straightforward. But, in their various current and future efforts to protect the sensitive environment close to home, Norway and Russia could very well end up discovering that they have more in common than they usually seem to recognize.

The analytical foundation of this article is discourse analysis. We tried to spell out at the beginning, and to show implicitly throughout this article, that texts possess power in their own right, and that understanding discourse is crucial in making better sense of foreign policy formation. Discourse analysis has enabled us to investigate how Norway's and Russia's approaches to the North are framed, socially produced and maintained, and how they are always in change. We feel there is a great, unfulfilled need for more interdisciplinary research into such diverse, highly technical, complex, and at the same time often politicized issues that polar research includes. 


\section{Acknowledgements}

We would like to thank two anonymous referees for their helpful comments and suggestions that significantly helped to improve the first version of this article. LCJ would like to thank the Norwegian Ministry of Defence for funding the study upon which his contribution to this article is based. We would also like to thank Chris Saunders for assistance with language.

\section{References}

Åkerstrøm Andersen N. 2003. Discursive analytical strategies: understanding Foucault, Koselleck, Laclau, Luhmann. Bristol: Policy Press.

Åtland K. 2008. Mikhail Gorbachev, the Murmansk initiative, and the desecuritization of interstate relations in the Arctic. Cooperation and Conflict 43, 289-311.

Åtland K. 2009. Russia's northern fleet and the oil industry-rivals or partners? Petroleum, security, and civil-military relations in the post-Cold War European Arctic. Armed Forces e Society 35, 362-384.

BBC 2009. Russia outlines Arctic force plan. BBC News, 27 March. Accessed on the internet at http://news.bbc.co.uk/ 2/hi/europe/7967973.stm on 10 April 2009.

Berge K.L. 2003. Hvor er makten i teksten? (Where is the power in texts?) In K.L. Berge et al. (eds.): Maktens tekster. (The texts of power.) Pp. 24-42. Oslo: Gyldendal Akademisk.

Blakkisrud H. \& Hønneland G. 2006a. The burden and blessing of space. In H. Blakkisrud \& G. Hønneland (eds.): Tackling space: federal politics and the Russian North. Pp. 193-203. Lanham, MD: University Press of America.

Blakkisrud H. \& Hønneland G. 2006b. The Russian North: an introduction. In H. Blakkisrud and G. Hønneland (eds.): Tackling space: federal politics and the Russian North. Pp. 1-24. Lanham, MD: University Press of America.

Borisov T. 2009. Bez boevyh pingvinov: Rossija sozdaet arktičeskuju gryppirovku vojsk bez militarizacsii regiona. (No fighting penguins: Russia creates Arctic force without militarizing the region.) Rossijskaja Gazeta, 30 March. Accessed on the internet at http://www.rg.ru/2009/03/30/ arktika.html on 12 April 2009.

Czarniawska B. 2004. Narratives in social science research. London: Sage Publications.

ECNA (Expert Commission for the Northern Areas) 2003. Mot nord! Utfordringer og muligheter i nordområdene. NOU 2003:32. (Towards the North! Challenges and opportunities in the High North. NOU 2003:32.) Oslo: Government Administration Services. Accessed on the internet at http://www.regjeringen.no/Rpub/NOU/20032003/032/ PDFS/NOU200320030032000DDDPDFS.pdf on 15 Feburary 2008.

Foucault M. 1972. The archaeology of knowledge. London: Routledge.

Gazprom 2003. Energičeskaja strategija Rossii na period do 2020 goda. (Russia's energy strategy towards 2020.) Moscow: Gazprom. English summary available on the internet at http://ec.europa.eu/energy/russia/events/doc/

2003_strategy_2020_en.pdf.

Hansen L. 2006. Security as practice: discourse analysis and the Bosnian war. London: Routledge.

Henriksen T., Sydnes A.K. \& Hønneland G. 2006. Law and politics in ocean governance: the UN fish stocks agreement and regional fisheries management regimes. Leiden: Martinus Nijhoff Publishers.

Hønneland G. 2003. Russia and the West: environmental cooperation and conflict. New York: Routledge.

Hønneland G. 2005. Barentsbrytninger: Norsk nordområdepolitikk etter den kalde krigen. (Barents breaking: Norweigan High North politics after the Cold War.) Kristiansand: Høyskoleforlaget.

Hønneland G. 2006. Kvotekamp og kyststatssolidaritet: norsk-russisk fiskeriforvaltning gjennom 30 år. (Quota battle and coastal state solidarity: Norwegian-Russian fisheries management through 30 years.) Bergen: Fagbokforlaget.

Hønneland G. \& Jensen L.C. 2008. Den nye nordområdepolitikken: Barentsbilder etter årtusenskiftet. (The new High North politics: Barents images after the turn of the millennium.) Bergen: Fagbokforlaget.

Isachenkov V. 2009. Russia plans to create Arctic military force. Washington Times, 27 March. Accessed on the internet at http://www.washingtontimes.com/news/2009/ mar/27/russia-plans-to-create-arctic-military-force- 1 on 10 April 2009.

Jensen L.C. 2007. Petroleum discourse in the European Arctic: the Norwegian case. Polar Record 43, 247-254.

Jensen Ø. 2008. Kontinentalsokkelens avgrensning utenfor 200 nautiske mil: norske og russiske perspektiver i de nordlige havområder. (Delimitation of the continental shelf beyond 200 nautical miles: Norwegian and Russian perspectives in the northern maritime areas.) Internasjonal Politikk 66, 563-589.

Keohane R.O. \& Nye J.S. 1977. Power and interdependence: world politics in transition. Boston: Little, Brown and Company.

Laclau E. \& Mouffe C. 1985. Hegemony e socialist strategy: towards a radical democratic politics. London: Verso.

Larsen H. 1997. Foreign policy and discourse analysis: France, Britain and Europe. London: Routledge.

Larsson R.L. 2006. Russia's energy policy: security dimensions and Russia's reliability as an energy provider. Stockholm: Swedish Defence Research Agency.

Løvås J. 2006. Barentsbløffen. (The Barents bluff.) Dagens Nxringsliv, 23 March, p. 2.

Ministry of Foreign Affairs 2005. Report no. 30 (2004-2005) to the Storting. Opportunities and challenges in the North. Oslo: Norwegian Ministry of Foreign Affairs. Accessed on the internet at http://www.regjeringen.no/upload/kilde/ ud/stm/20042005/0001/ddd/pdts/stm200420050001ud_ dddpdts.pdf on 15 Feburary 2008.

Ministry of Foreign Affairs 2006. The Norwegian Government's High North strategy. Oslo: Norwegian Ministry of Foreign Affairs. Accessed on the internet at http://www.regjeringen. no/upload/UD/Vedlegg/strategien.pdf on 21 Feburary 2008. 
Morgenthau H.J. 1973. Politics among nations: the struggle for power and peace. 5th edn. New York: Knopf.

Neumann I.B. 1994. A region-building approach to northern Europe. Review of International Studies 20, 53-74.

Neumann I.B. 2001. Mening, materialitet, makt: en innføring $i$ diskursanalyse. (Meaning, materiality, power: an introduction to discourse analysis.) Bergen: Fagbokforlaget.

Norwegian Government 2009. Nye byggesteiner i nord: neste trinn i Regjeringens nordområdestrategi. (New building blocks in the North: the next step in the Government's High North strategy.) Accessed on the internet at http://www. regjeringen.no/upload/UD/Vedlegg/Nordomr\%C3\% A5dene/byggesteiner_nord.pdf on 27 March 2009.

Office of the Prime Minister 2005. The Soria Moria declaration on international policy. Oslo: Office of the Prime Minister. Accessed on the internet at http://www.regjeringen.no/en/ $\mathrm{dep} /$ smk/Documents/Reports-and-action-plans/Rapporter/ 2005/The-Soria-Moria-Declaration-on-Internati.html?id= 438515 on 18 November 2007.

Parfitt T. 2007. Miles below the North Pole, Russian mini-subs lay claim to Arctic wealth. Guardian Unlimited, 3 August. Accessed on the internet at http:// www.guardian.co.uk/world/2007/aug/03/russia.oil on 21 March 2010.

Parfitt T. 2009. Russia plans military force to patrol Arctic as "cold rush" intensifies. Guardian Unlimited, 28 March. Accessed on the internet at http://www.guardian.co.uk/ world/2009/mar/28/russia-gas-oil-arctic-nato on 10 April 2009.

Parker I. 1992. Discourse dynamics: critical analysis for social and individual psychology. London: Routledge.

Phillips N. \& Hardy C. 2002. Discourse analysis: investigating processes of social construction. Thousand Oaks, CA: Sage Publications.

Putin V. 2001. Annual address to the Federal Assembly. Accessed on the internet at http://kremlin.ru/eng/speeches/2001/ 04/03/0000_type70029type82912_70660.shtml on 17 Feburary 2008.

Putin V. 2002. Annual address to the Federal Assembly. Accessed on the internet at http://kremlin.ru/eng/speeches/2002/ 04/18/0000_type70029type82912_70662.shtml on 18 February 2008.

Putin V. 2003. Annual address to the Federal Assembly. Accessed on the internet at http://kremlin.ru/eng/speeches/2003/ 05/16/0000_type70029type82912_44692.shtml on 18 February 2008.

Putin V. 2004. Annual address to the Federal Assembly. Accessed on the internet at http://kremlin.ru/eng/speeches/2004/ 05/26/1309_type70029type82912_71650.shtml on 18 February 2008.

Putin V. 2005. Annual address to the Federal Assembly. Accessed on the internet at http://kremlin.ru/eng/speeches/2005/ 04/25/2031_type70029type82912_87086.shtml on 18 February 2008.

Putin V. 2006. Annual address to the Federal Assembly. Accessed on the internet at http://kremlin.ru/eng/speeches/2006/ 05/10/1823_type70029type82912_105566.shtml on 18 February 2008.

Putin V. 2007. Annual address to the Federal Assembly. Accessed on the internet at http://kremlin.ru/eng/speeches/2007/ 04/26/1209_type70029type82912_125670.shtml on 17 February 2008.

Putin V. 2008. Speech at expanded meeting of the State Council on Russia's development strategy through to 2020. Accessed on the internet at http://kremlin.ru/eng/speeches/2008/02/08/ 1137_type82912type82913_159643.shtml on 18 February 2008.

Russian Security Council 2009a. Osnovi gosudarstvennoj politiki Rossijskoj Federatcii v Arktike na period do 2020 goda $i$ dal'nejšuju perspektivu. (Principles of the Russian Federation's state policy in the Arctic in the period to 2020 and in the longer perspective.) Security Council of the Russian Federation. Accessed on the internet at http://www.scrf.gov.ru/documents/98.html on 12 April 2009.

Russian Security Council 2009b. Natsional'naia bezopasnost' Rossii: dokumenty, otnociashchiesia $k$ razlichnym aspektam natsional'noj bezopasnosti Rossii. (Russia's national security: documents concerning different aspects of Russia's national security.) Security Council of the Russian Federation. Accessed on the internet at http://www.scrf.gov.ru/ documents/sections/3 on 12 April 2009.

Schiffrin D., Tannen D. \& Ehernberger Hamilton H. 2003. Introduction: what is discourse analysis? In D. Schiffrin et al. (eds.): The handbook of discourse analysis. Pp. 1-10. Malden, MA: Blackwell.

Scott J.C. 1998. Seeing like a state: how certain schemes to improve the human condition have failed. New Haven: Yale University Press.

Searle J.R. 1969. Speech acts: an essay in the philosophy of language. Cambridge: Cambridge University Press.

Skagestad O.G. (n.d.) Where is the "High North"? The High North-an elastic concept? Accessed on the internet at http://www.geopoliticsnorth.org/index.php?option=com_ content\&view=articlesid=1:an-international-researchproject\&catid=1:latest-news\&limitstart=1 on 26 March 2010.

Skedsmo P. 2005. "Doing good" in Murmansk?: civil society, ideology and everyday practices in a Russian environmental NGO. FNI-rapport 14/2005. Lysaker: Fridtjof Nansens Institute.

Stokke O.S. \& Hønneland G. (eds.) 2007. International cooperation and Arctic governance: regime effectiveness and northern region building. London: Routledge.

Tonkiss F. 1998. Analysing discourse. In C. Seale (ed.): Researching society and culture. Pp. 245-260. London: Sage.

Wæver O. 1995. Securitization and desecuritization. In R.D. Lipschutz (ed.): On security. Pp. 46-86. New York: Columbia University Press.

Winther Jørgensen M. \& Phillips L. 1999. Diskursanalyse som teori og metode. (Discourse analysis as theory and method.) Frederiksberg: Roskilde Universitetsforlag. 